\title{
Shallow geological environment of Krishna-Godavari offshore, eastern continental margin of India as inferred from the interpretation of high resolution sparker data
}

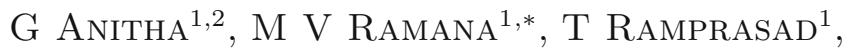 \\ P DeWANGAN ${ }^{1}$ and M ANURADHA ${ }^{1,3}$ \\ ${ }^{1}$ CSIR - National Institute of Oceanography, Dona Paula, Goa 403004 , India. \\ ${ }^{2}$ National Centre for Antarctica Research, Sada Headland, Vasco da Gama 403 804, India. \\ ${ }^{3}$ Andhra Pradesh State Ground Water Department, Eluru 534 002, India. \\ ${ }^{*}$ Corresponding author.e-mail: ramana@nio.org
}

Krishna-Godavari offshore basin, a part of the eastern continental margin of India is a proven petroliferous basin. Recent drilling in this area in search of gas hydrates reveals that the upper $\sim 300 \mathrm{~m}$ thick Quaternary-Recent strata comprised of nannofossil bearing rich clays and, fractures/faults are the suitable zones for gas hydrates accumulation. Therefore, the knowledge about the shallow geological environments and its architecture are significantly important in assessing the gas hydrates potential of this area. In order to enhance the geological understanding, the newly acquired high resolution seismic (HRS) reflection data in this gas hydrates prone area is interpreted. The processed seismic sections show a maximum penetration of $562 \mathrm{~ms}$ TWT $(\sim 450 \mathrm{~m})$ underneath the seabed with high resolution stratification. An attempt has been made to: (i) deduce the shallow geological environment from the reflection characteristics, and, (ii) assign tentative ages under the constraints of drilling/coring results. We further explained the observed folded structures on the surface and subsurface through a mechanism linked to shale tectonism and neotectonic activity.

\section{Introduction}

Krishna-Godavari (KG) offshore basin (figure 1) began to draw the attention of explorationists due to its proven hydrocarbon potential over the past two and a half decades. Increasing demand for oil and natural gas led the Ministry of Petroleum and Natural Gas (Government of India) to search for an alternate to the conventional hydrocarbons. In that endeavour, it was found that gas hydrates (pure form of methane gas) could be a suitable substitute due to its abundant occurrence in the marine slope sediments as well as permafrost regions (Kvenvolden 1993). Several researchers used the multichannel seismic reflection (MCS) data to infer the presence of gas hydrates by mapping bottom simulating reflector (BSR, an anomalous seismic reflector, and a gas hydrates related geophysical proxy) that represents the base of gas hydrates stability zone. The gas hydrates fields of Nankai trough, Blake ridge, Hydrate ridge, Siberia, etc., are the best known examples inferred from the BSRs.

The resource map of India (NIO 1997) in conjuncture with the inferred BSRs (NIO 2001) reveal that the gas hydrates can also occur along the Indian continental margins. The multidisciplinary investigations (NIO 2001) further

Keywords. KG offshore; gas hydrates; high resolution sparker data; gas upthrust; mud diapirism. 


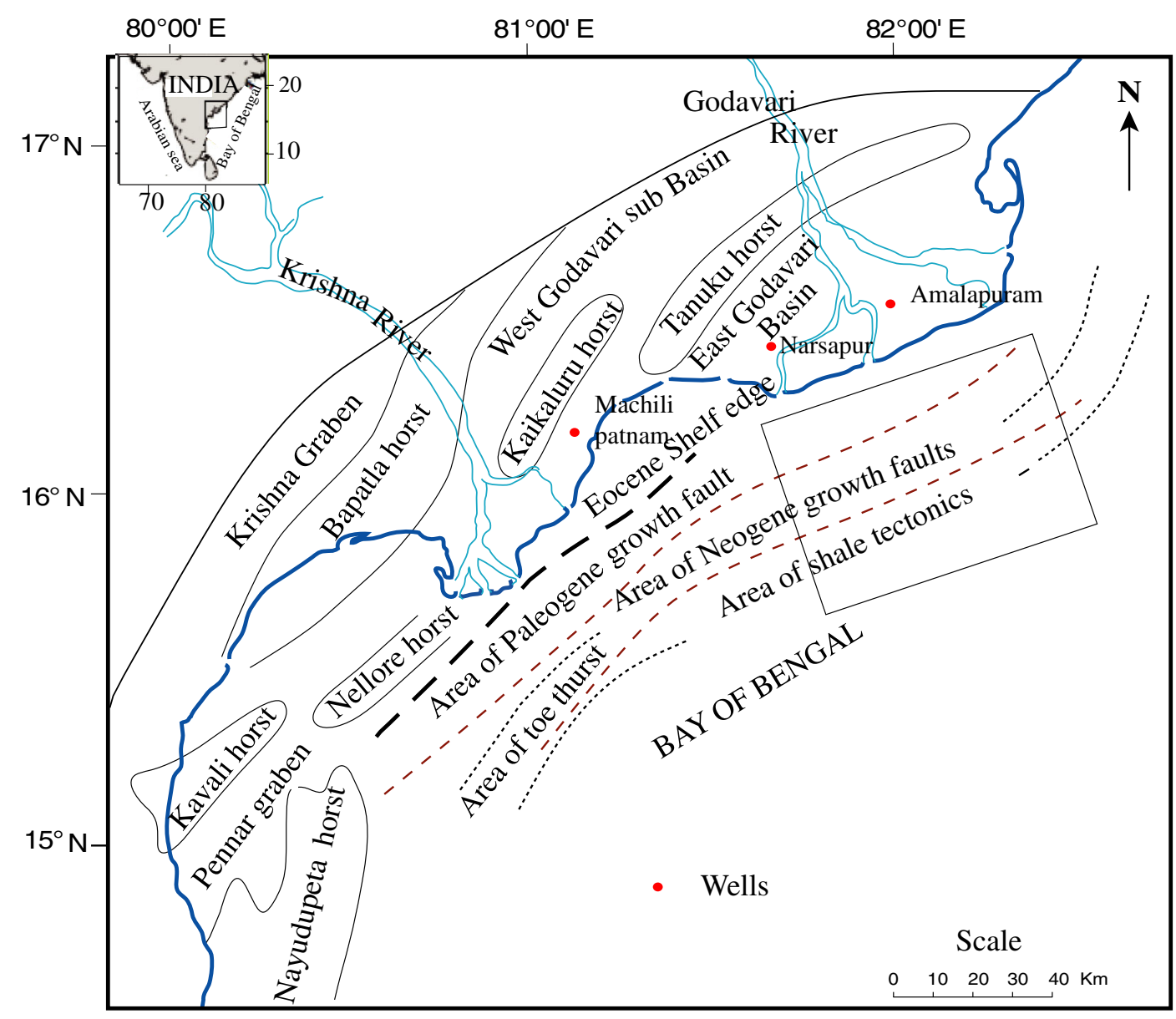

Figure 1. Map showing the structure and tectonic frame work of KG basin, east coast of India. Krishna and Godavari are the two major perennial rivers flowing into the Bay of Bengal in the study area. The onshore is dominated by NE-SW trending horst and grabens, and the grabens are filled with Precambrian to Recent sediments. The Eocene shelf edge, Paleogene and Neogene growth faults, toe thrust fault and shale diapirism are some of the characteristic features of the KG offshore (after Rao and Mani 1993; Rao 2001; Bastia 2004; Dewangan et al. 2010).

facilitated in selection of probable locations for ground truthing. Drilling/coring through the slope sediments onboard JOIDES Resolution during NGHP Expedition-01 during 2006 confirmed the presence of a fully developed gas hydrate system in the KG, Mahanadi offshores and in Andaman Sea under varied tectonic (passive and active margin) settings. Further, the drilling results amply testify that the seismic data alone is inadequate to confirm the presence of gas hydrates since some locations associated with BSRs did not encounter gas hydrates during drilling, which was the case elsewhere also.

The detectable layer thickness in general on the MCS data is the function of source frequency (10-120 Hz, with a dominant central frequency of $\sim 50 \mathrm{~Hz}$ ). With this dominant frequency and velocity $(1500 \mathrm{~m} / \mathrm{s})$, the optimum detectable layer thickness could be around $30 \mathrm{~m}$. Gas hydrate deposits are found to occur in different types, i.e., disseminated, nodular, layered, massive (Sloan 1990) and fracture fill type (Collett et al. 2008). The reported thickness of the gas hydrate chunks varies from few centimetres to few meters with an exception of one or two locations, where the thickness is $>100 \mathrm{~m}$. The lateral extent of these deposits have always remained speculative and uncertain. The limited vertical and lateral extent of the gas hydrates deposits constrains the efficacy of the conventional MCS data in exploration activity. Therefore the conventional seismic data is inadequate to draw any conclusion on the occurrence of gas hydrates. Alternately, high resolution seismic (HRS) reflection data due to its high frequency $(1000-1200 \mathrm{~Hz})$ source characteristics can provide high resolution strata and fine scale structures/features.

Interpretation of the HRS reflection data acquired using digital sparker system in the KG offshore basin revealed the presence of several gas escape features such as pockmarks, gas vents, chimneys, gas upthrust, and gas saturated zones, prominent topographic mounds, fluid/gas expulsion pathways, and regional fault system (Ramana et al. 2009; Dewangan et al. 2011; 
Ramprasad et al. 2011). Further, the previous studies aided in mapping BSRs on the industry acquired MCS datasets. The HRS reflection records under the constraint of swath bathymetry mosaic depict the imprints of slumping/sliding predominant in the upper slope sediments (Ramprasad et al. 2011). Further, the sedimentological data at site NGHP-01-03B, located in the vicinity of the seismic profiles (AD-94-17, AD94-16, and HRS line L-09-10), is used to infer the shallow subsurface geology. The well at this location penetrated $\sim 300 \mathrm{~m}$ below the seabed, and the sediments comprised of nannofossil rich clays with occasional incursions of $\sim 10-20 \mathrm{~m}$ thick foraminifera bearing clay zones (Collett et al. 2008) with occasional presence of carbonate/pyrite bands and authigenic carbonates (figure 5).

An attempt has been made in this study to decipher the shallow subsurface geology and associated fine scale geological features and gas escape features, since this shallow zone of 300-400 m below the seabed hosts the gas hydrate deposits. Also, plausible mechanism has been suggested to explain the observed features on the seismic sections such as fault controlled subsidence zones, long wavelength topography undulations, etc. Further, an attempt has been also made to assign tentative ages to different reflectors under the constraints of drilling/coring and published results.

\section{Geology}

The KG basin, a pericratonic onshore basin is in existence since Jurassic (Rao 2001; Sahu 2005; Gupta 2006) and extends offshore beyond the midslope along the eastern continental margin of India. This basin extends between Visakhapatnam in the north and Ongole in south, and occupies an area of $\sim 28000 \mathrm{~km}^{2}$ on land, and $\sim 145000 \mathrm{~km}^{2}$ offshore, respectively. The onshore KG basin is characterised by several $\sim \mathrm{NE}-\mathrm{SW}$ trending horst and graben like structures, some of which extend offshore (Sahu 2005). A portion of the offshore basin covering shelf and mid-slope region is filled with late Carboniferous to Holocene sediments (Rao 2001), while the deeper portion of the basin including the lower slope and further offshore is filled with the Cretaceous-Recent sediments (Curray et al. 1982; Pateria et al. 1992). These sediments rest over the oceanic basement (Ramana et al. 1994) of Early Cretaceous age. The onshore grabens are filled with 3-6 km thick volcanic lava flows comprising intertrappean clay, lime stone and sand beds (Rao and Mani 1993; Rao 2001; Sahu 2005), The offshore basin comprises predominantly clay stone with sand and siltstone beds, and the basement is overlined by the lower Cretaceous and
Paleocene shales with intertrappen Razole volcanic flows (Rao and Mani 1993; Rao 2001; Sahu 2005; Gupta 2006). The Eocene Vadaparru shale, thin Oligocene clay stone, Miocene-early Pliocene Ravva sandstone formations, and Godavari clay of Pleistocene to Recent are the geological successions resting on the top of Paleocene (Rao 2001; Bastia et al. 2006; Bastia and Nayak 2006). The shallow geological succession mainly comprises clay/silt dominant sediments enriched with foraminifera (Collett et al. 2008). Preliminary dating of these sediments revealed that the upper $300 \mathrm{~m}$ strata belongs to late Pleistocene to Recent, and these sediments appear to be deposited with variable sedimentation rates (Collett et al. 2008; Mazumdar et al. 2009).

\section{Data}

A 10 Kilo Joules $(\mathrm{kJ})$ energy source sparker system (Geo-Resources B V, The Netherlands) with a single channel digital streamer was deployed and acquired the HRS reflection data along the pre-determined cruise tracks (figure 2) under the institute's gas hydrates research programme. About 350 line kilometres HRS data (figure 3a, $\mathrm{b}$ and $\mathrm{c}$ ) has been analysed along with the industry acquired MCS data (figure 4) to understand the subsurface geological framework. The lithology (figure 5) derived from the drill well data of NGHP-01 Expedition in the KG Basin is incorporated to correlate the major seismic horizons.

\section{Results}

The depth of the seabed varies from $\sim 375 \mathrm{~m}$ on the upper shelf to $\sim 1600 \mathrm{~m}$ on the lower slope region with an average gradient of 1:37 in the study area. The seafloor particularly in the upper and beginning of the mid-slope region is seen protruded by $<2.0-4.0 \mathrm{~km}$ wide features with relief of 30 to $80 \mathrm{~ms}$ (figure $3 \mathrm{a}$ and $\mathrm{b}$ ). The seismic sections depict nine reflectors in the mid-slope sediments and about four in the upper and lower slope regions, respectively. A maximum penetration of $\sim 562 \mathrm{~ms}(\sim 450 \mathrm{~m}$, by assuming $1600 \mathrm{~m} / \mathrm{s}$ as the sediment velocity) below the seabed is noticed in the study area. A distinct $60-80 \mathrm{~ms}$ thick upper sequence comprising recent sediments overlie the LGM surface, and the thickness of this sediment pack tapers gradually towards offshore end (figure $3 \mathrm{a}-\mathrm{c}$ ). The sediments in the upper slope are characterised by three sequences of variable thickness $30-60 \mathrm{~ms}(24-48 \mathrm{~m})$ bounded by four 


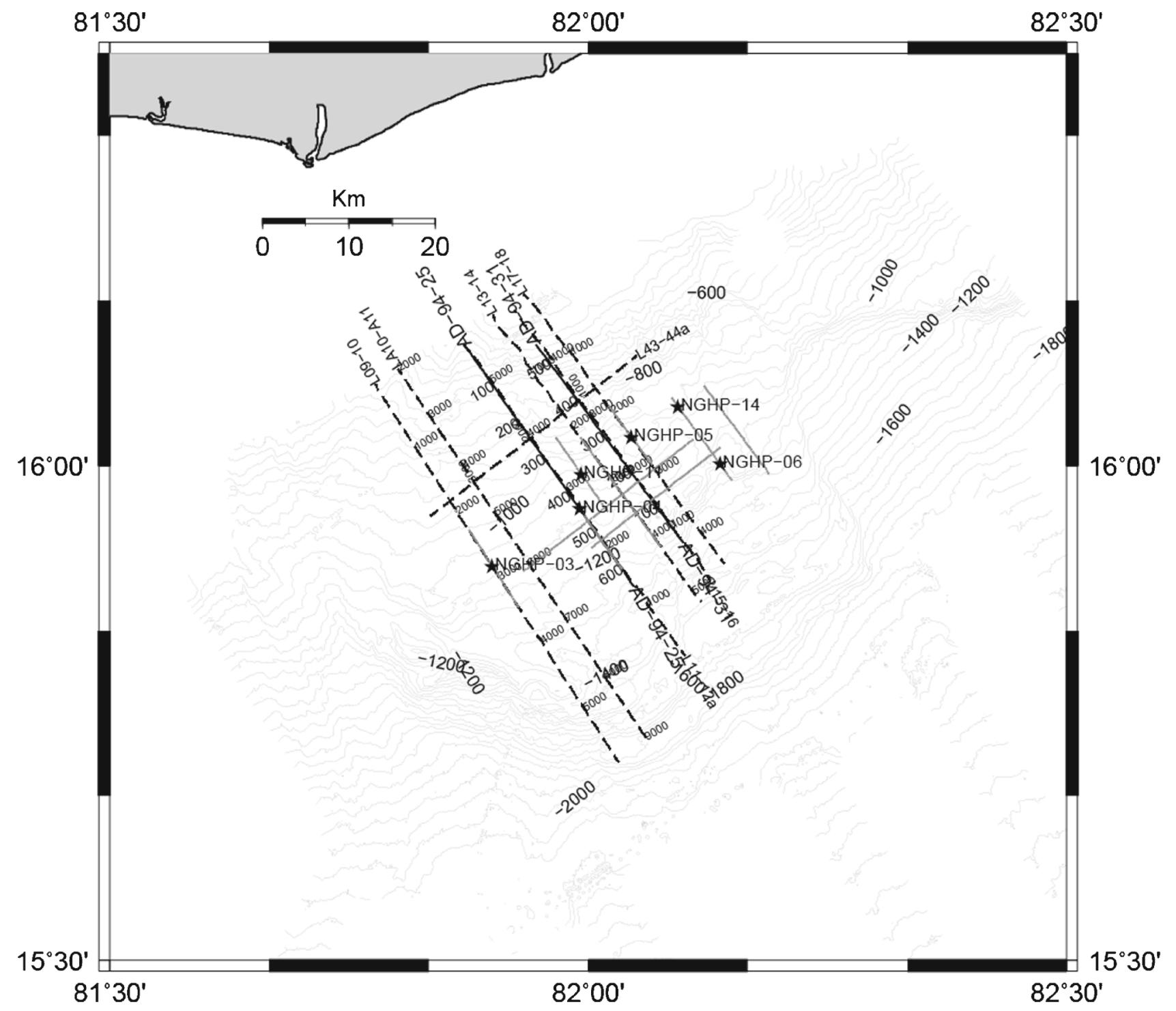

Figure 2. Map showing the tracks along which the high resolution seismic reflection (HRS) data acquired using $10 \mathrm{~kJ}$ Sparker System. The $\sim \mathrm{NW}-\mathrm{SE}$ trending tracks represent the dip lines and $\sim \mathrm{NE}-\mathrm{SW}$ tracks represent strike lines. The detailed bathymetry derived from the multibeam data has been incorporated. The depth contours are annotated at every $200 \mathrm{~m}$ interval. Stars indicate the locations of NGHP-01 expedition drill sites. Solid line represents the location of MCS section (AD94-25). Thin light lines represent the BSRs on industry acquired MCS data.

major horizons/reflectors. The upper slope is seen associated with cut and fill type paleochannels (figure $3 \mathrm{~d}$ ) and blanking zones with variable widths $(0.4-0.8 \mathrm{~km})$. Faulting due to intense gas upthrusts and gas saturation zones are some of the characteristic features of the upper slope sediments. The sediments further offshore are heavily disturbed by intense faulting and gas-upthrust features. A mini basin with $168 \mathrm{~ms}(135 \mathrm{~m})$ thick sediments exists over the reflector prominent at a depth of $1.56 \mathrm{~s}$ (figure 3d). A fault controlled graben like structure is conspicuous along the line 11-12a in the upper slope region (figure 3c), and is characterised by number of parallel to subparallel and broken reflectors. Further offshore, the number of reflectors reduces to four only and continues to lower slope.
The lower slope region is characterised by $1.5-$ $2.5 \mathrm{~km}$ wide positive topography features with subsurface expression, and the relief of these positive features varies from $40-100 \mathrm{~ms}(32-80 \mathrm{~m})$ from the adjacent seafloor topography.

\section{Discussion}

\subsection{Geomorphology and subsurface geological architecture}

The depth to the seabed varies from $<375 \mathrm{~m}$ on the upper slope to $>1600 \mathrm{~m}$ in the lower slope region. The seabed topography of the upper and lower slope regions is characterised by high 

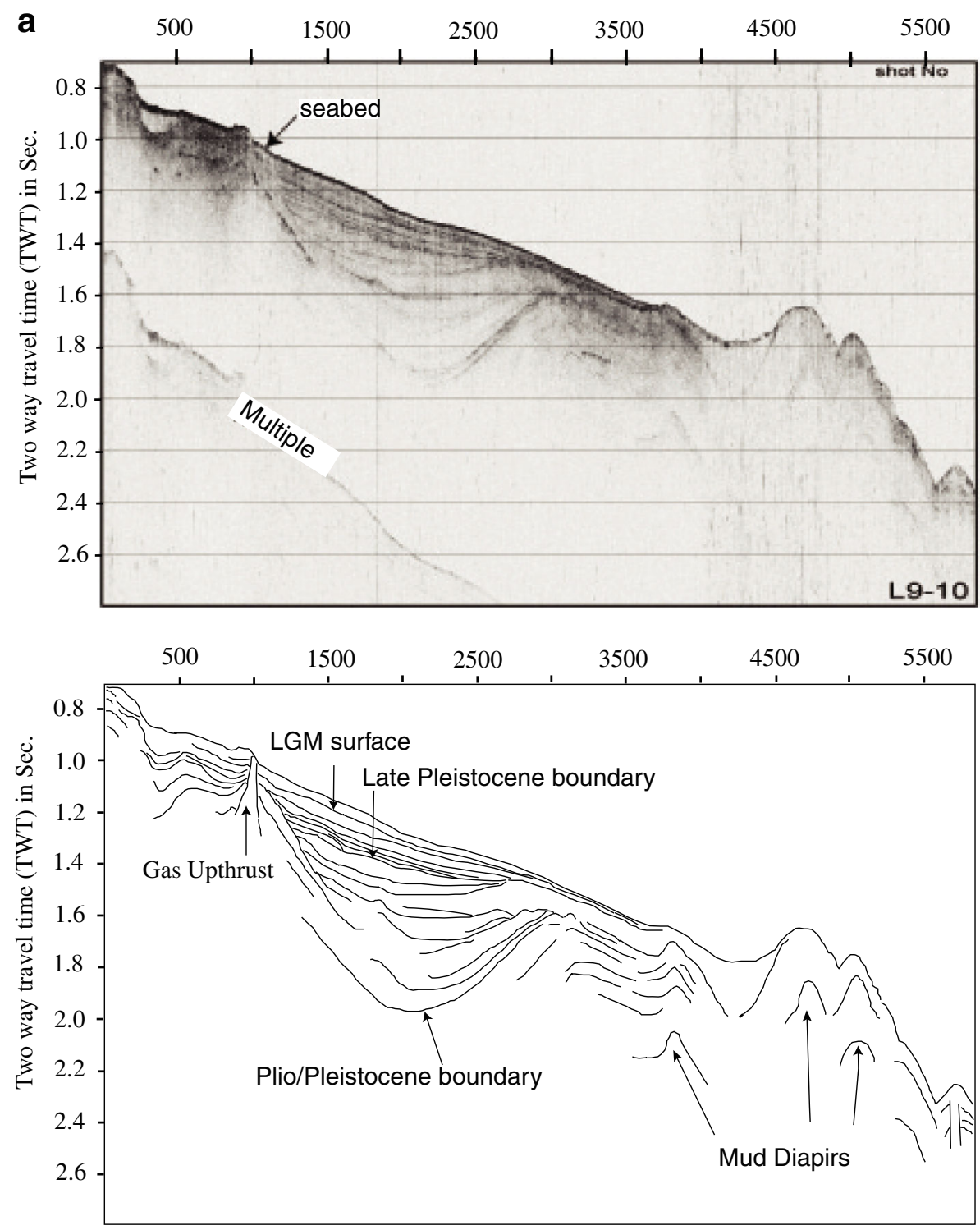

Figure 3a. Processed HRS sections along the tracks (a) L09-10, (b) L10-A11, (c) L11-12a and (d) L11-12a (refer figure 2 for location) with interpreted line drawings.

relief and broad wavelength undulations, while the mid-slope is devoid of major order undulations and is characterised by smooth topography. The HRS sections depict a maximum penetration of $\sim 450 \mathrm{~m}$ in the mid-slope and lower slope regions and the sediments below the seabed are mostly stratified. The bottom layers in the upper slope are seen associated with irregular surface (figure $3 \mathrm{~d}$ ) giving rise to an appearance of cut and fill type channel/a mini-graben. Configuration of this feature, and the internal reflection-pattern suggest that this feature could be an erosional feature rather than a paleochannel, and appears to be a result of either strong contour currents or massive mudflow during the past (figure $3 \mathrm{~d}$ ).

The disappearance of a large number of reflectors (stratification) in the deep offshore (lower slope) is due to gas masking/saturation (figure 3ac). The mud transport deposits, turbidity flows, mud diapirs, blanking zones, gas upthrust, etc., are some of the typical gas escape features common in the KG offshore basin (Bastia et al. 2006; Bastia and Nayak 2006; Ramana et al. 2006, 2009; Shanmugam 2009; Shanmugam et al. 2009; Dewangan et al. 2010). Impact of these features can be seen in the form of a large number of faults and columnar type gas vents/gas chimneys (figure 3c). The neotectonic activity and reactivation of some of these faults in conjuncture with the upward migration of large volumes of fluid/free gas through these week zones destabilised the sediment column, and resulted in the subsidence of the strata in the upper mid-slope region (figures $3 \mathrm{c}$ and 4). 

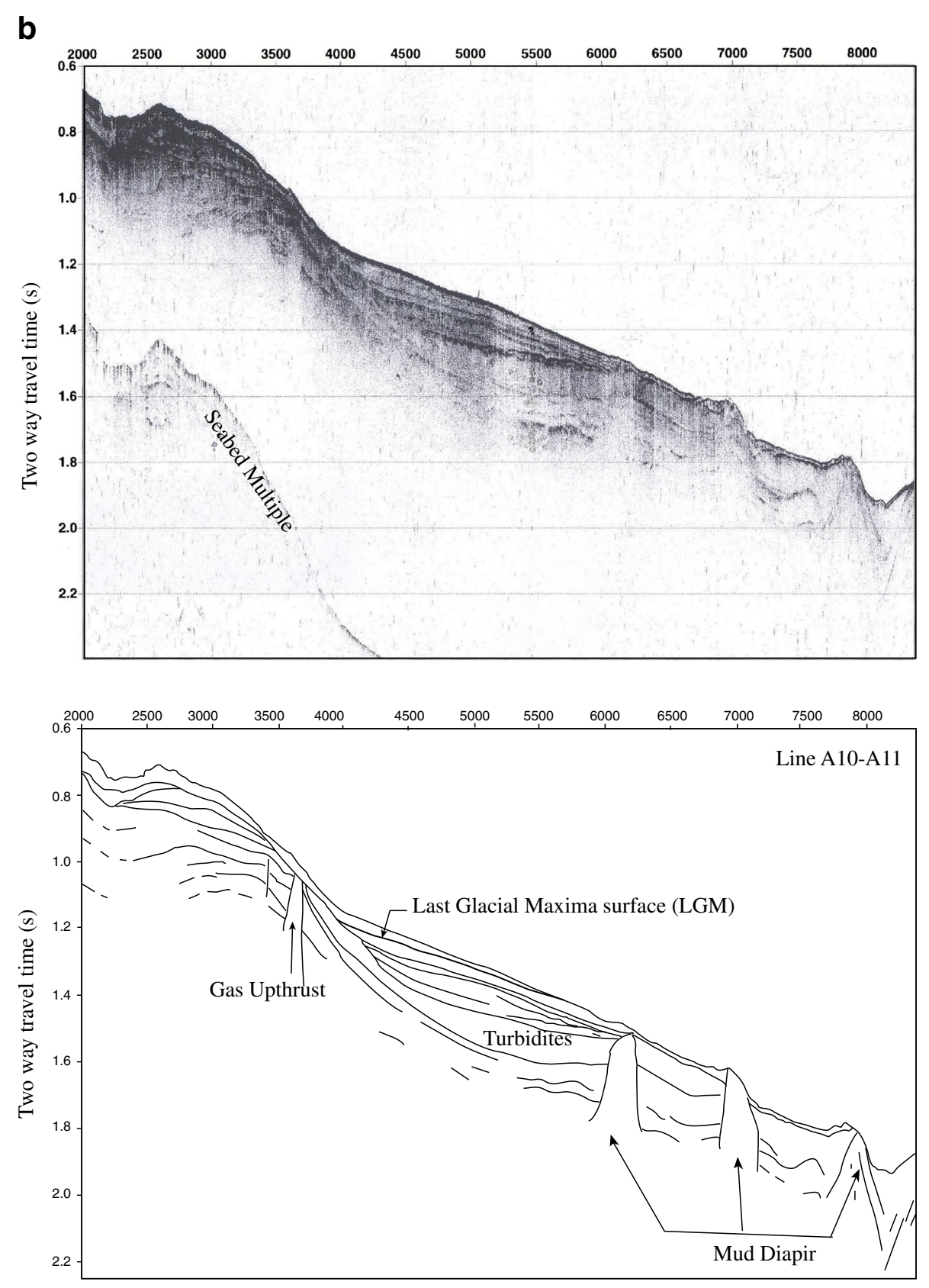

Figure 3. (Continued.)

The seismic section (figure 3c) also depicts positive bathymetry features (folded structure) towards lower slope region. Similar features in the KG offshore basin have been interpreted as the topographic mounds manifested by either shale diapirism or neotectonic activity (Dewangan et al. 2010). The shallow subsurface geology (upto $300 \mathrm{~m}$ ) has been inferred by correlating the prominent reflectors (figure $3 \mathrm{a}-\mathrm{c}$ ) with that of the lithology (figure 5) derived from the sedimentological analysis of the core at site NGHP01-03B (Collett et al. 2008). Some of the closely spaced reflectors correspond to the nannofossil rich $\sim 10-20 \mathrm{~m}$ wide clay zones. The occasionally seen strong patchy reflectors have been correlated with the reported carbonate/pyrite bands (Collett et al. 2008).

\subsection{Sedimentation rates}

Variable sedimentation rates are reported in the KG offshore basin. For example: the sedimentation rate of $1.06 \mathrm{~m} / \mathrm{kyr}$ has been reported for the shelf environment (Raju et al. 1994), while sedimentation rates ranging from 0.07 to $0.125 \mathrm{~m} / \mathrm{kyr}$ have been reported for the upper Cretaceous to Miocene strata. From the study of a $313 \mathrm{~m}$ long 

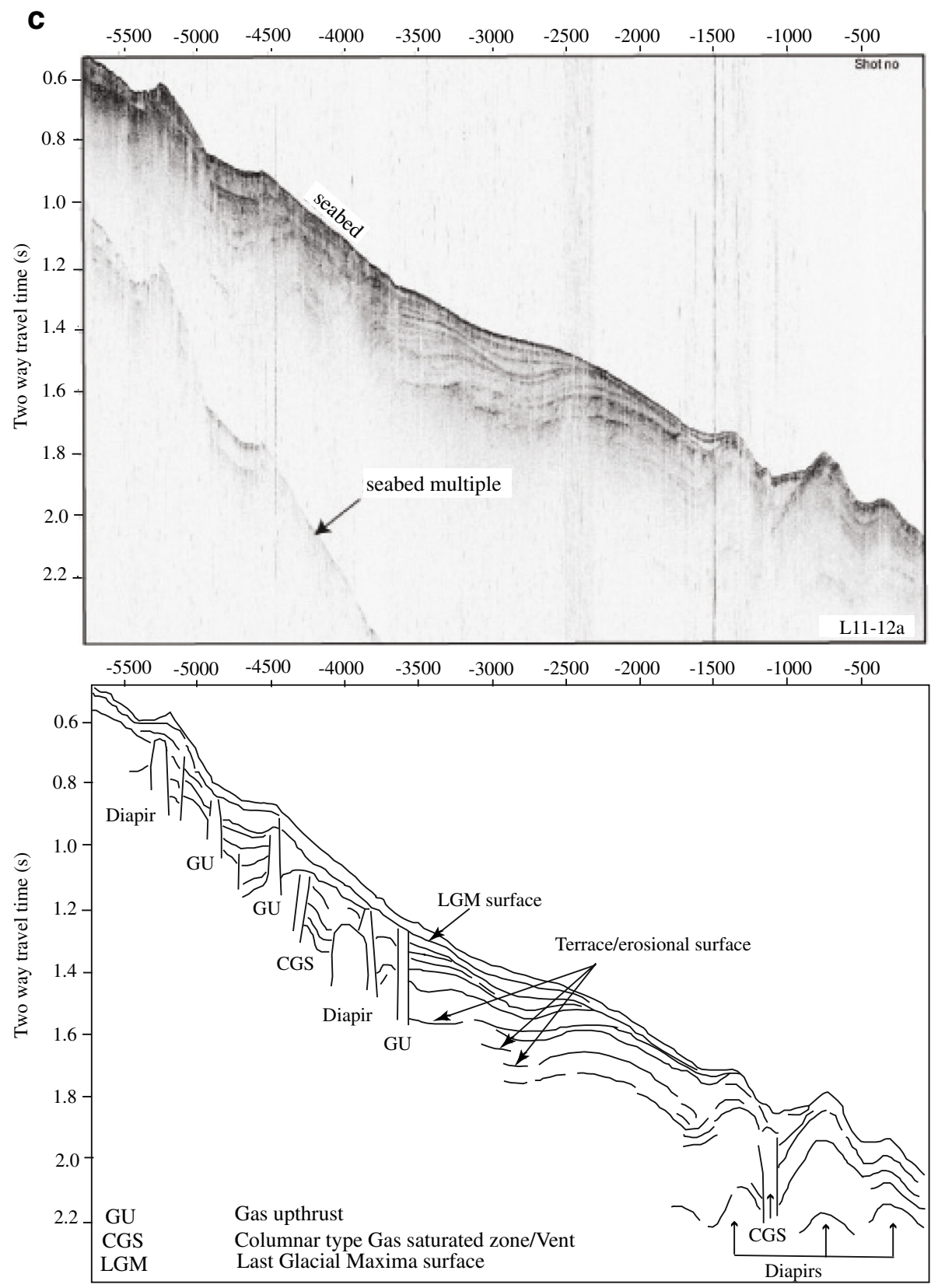

Figure 3. (Continued.)

conventional core in the deep water sediments of the KG basin (Rao and Mani 1993), Pliocene age $(\sim 5.3 \mathrm{Ma})$ has been inferred to the bottom of the core, which approximately yields an average sedimentation rate of $0.59 \mathrm{~m} / \mathrm{kyr}$. The dating of the sediment samples in the NGHP-01 expedition cores indicated an average sedimentation rate $0.15 \mathrm{~m} / \mathrm{kyr}$ (Collett et al. 2008). A recent study of $30 \mathrm{~m}$ long core in the $\mathrm{KG}$ offshore revealed high sedimentation rates of $2.483-0.86 \mathrm{~m} / \mathrm{kyr}$ for the upper 5 to $6 \mathrm{~m}$, and $0.175 \mathrm{~m} / \mathrm{kyr}$ for the rest of the core length, respectively (Mazumdar et al. 2009, 2012). From the above variable sedimentation rates, we adopted three sedimentation rates that can represent the shelf/upper slope, midslope and lower slope regions to infer the tentative ages and stratigraphy under the constraints of drill well data (Collett et al. 2008). The upper sediment sequence of $\sim 48 \mathrm{mbsf}$ in the upper slope region appears to be deposited with a high sedimentation rate of $>2 \mathrm{~m} / \mathrm{kyr}$ over the LGM surface (figure $3 \mathrm{a}-\mathrm{c}$ ). Further offshore, the sedimentation rate appears to decrease gradually from $\sim 2$ to $<1 \mathrm{~m} /$ kyr for the mid-slope $(700-1100 \mathrm{~m}$ water depths) sediments. The deeper sediments appear to be deposited with a sedimentation rate of about $0.17 \mathrm{~m} / \mathrm{kyr}$. The bottommost reflector in the mid-slope region has been inferred as the 


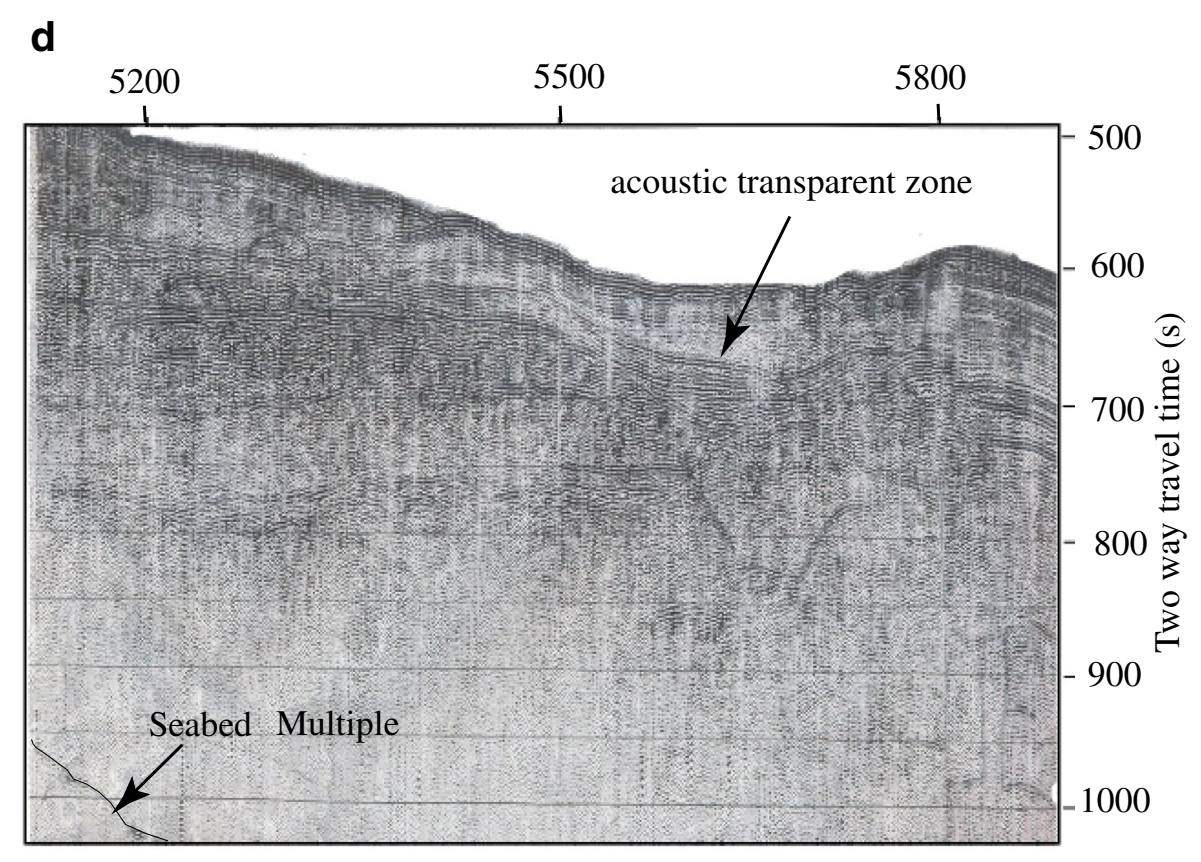

Line drawing of interpreted seismic profile

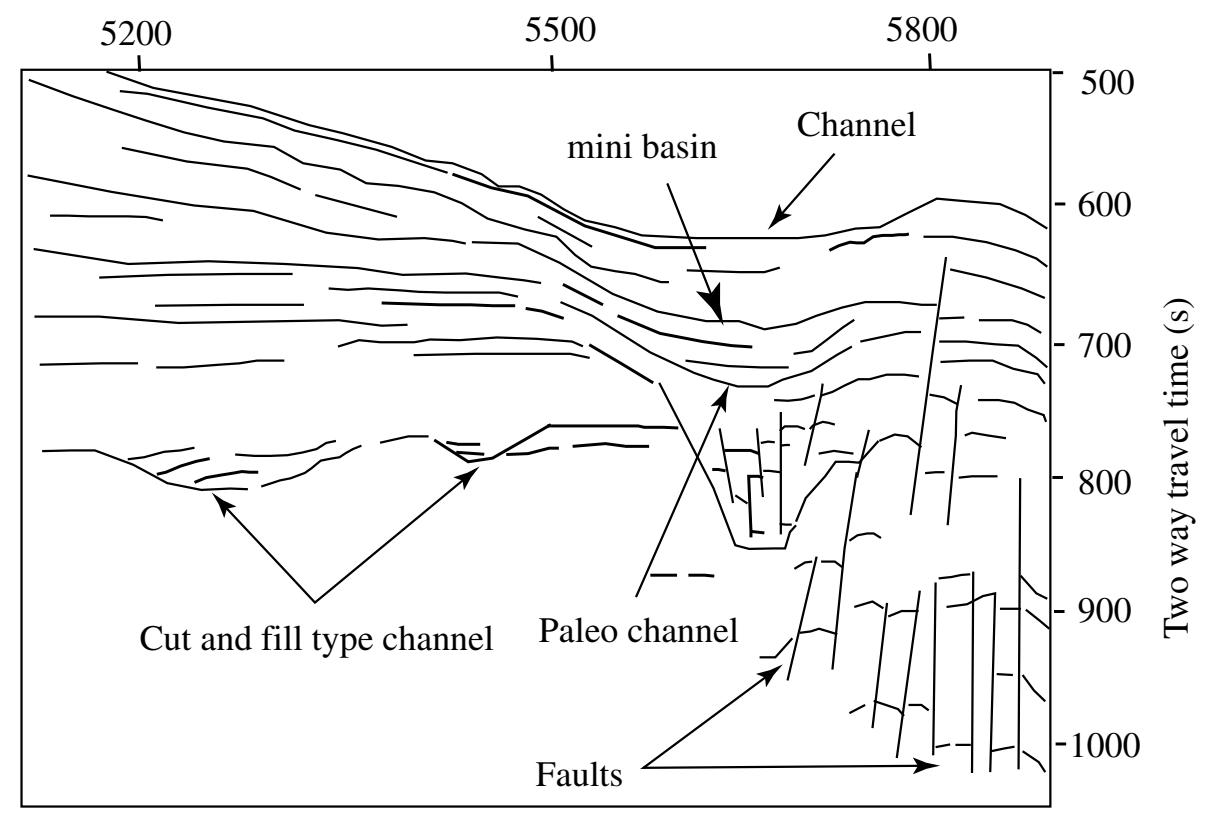

Figure 3. (Continued.)

Plio-Pleistocene boundary (figure 3a) under the constraints of these sedimentation rates. If the sedimentation rate of $\sim 1 \mathrm{~m} / \mathrm{kyr}$ has been considered, then the deepest reflector on the HRS section (figure $3 \mathrm{~b}$ and $\mathrm{c}$ ) in the mid-slope region represents the mid-Pleistocene age, otherwise, it represents late Pleistocene horizon with $\sim 0.17 \mathrm{~m} / \mathrm{kyr}$ sedimentation rate.

\subsection{Fluid/gas expulsion}

To examine the signatures of the fluid/gas expulsions from the deeper horizons, we have interpreted the MCS data along the line AD-94-25 (figure 4a) and integrated the structural information with the HRS data. This MCS section depicts a maximum penetration of $>3 \mathrm{~s}(\sim 3.5 \mathrm{~km}$ with $2400 \mathrm{~m} / \mathrm{s}$ average velocity in sediments) and intense faulting. The folded/domal shaped structures visible on this MCS section have been interpreted as the mound manifested by shale tectonism (Dewangan et al. 2010). These faults affect not only the upper PlioPleistocene sequence but also the mid-late Miocene horizons. Some other significant features on the section are: growth faults, anticline like structures, faults, gas vents (manifested by gas/fluid 

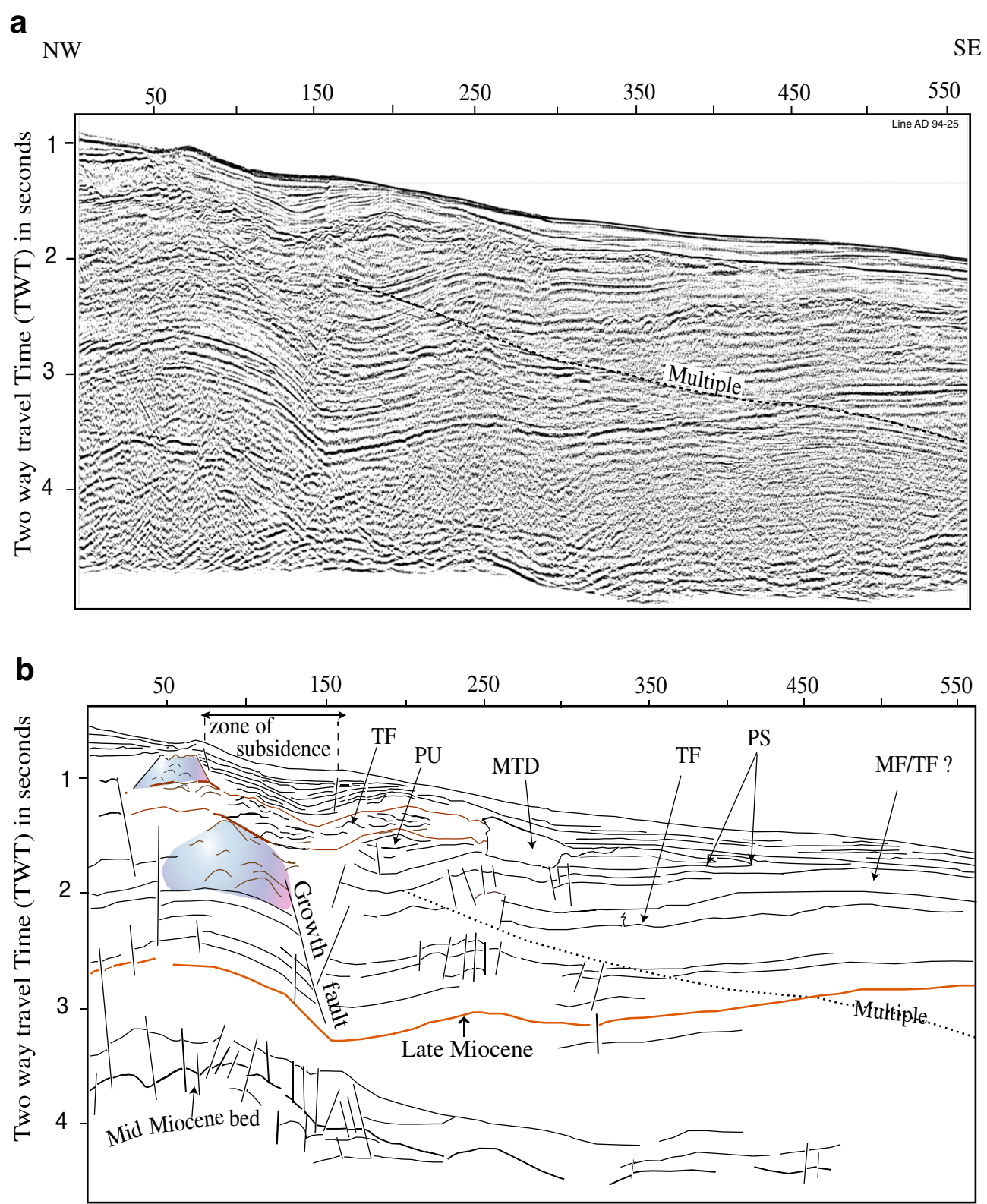

LEGEND

$\begin{array}{llr}\text { Carbonate buildups } & \text { PU Pull-up structure due to gas upthrust } \\ \text { TF } & \text { Turbidity flow } & \text { PS Pinch-out structure } \\ \text { | } & \text { Faults } & \text { MF/TF Mass flow/turbidity flow }\end{array}$

Figure 4. Interpreted MCS profile AD94-25. Zone of subsidence is shown with dashed lines. Upwelling of interpreted midMiocene and late Miocene beds, and the influence upwelling seen is in the form of anticline/domal shape up to Plio-Pleistocene. The seismic section also shows extensive faulting.

expulsion), fault controlled subsidence, carbonate build-ups, turbidite flows, mass transport deposits and velocity pull-up structures caused by gas upthrust. Apart from these features, the section also depicts the presence of pinchout structures at varied depths. The shallowing character of the loci of these pinchout structures may indicate the imprints of sea level transgression/regression during the past (late Pleistocene).

Excessive formation pressures were reported in the KG offshore basin (Rao and Mani 1993; Chatterjee et al. 2010) and these pressures affected the Miocene sequence to form folded/domal shaped structure (figure 4a). The overlying sedimentary 


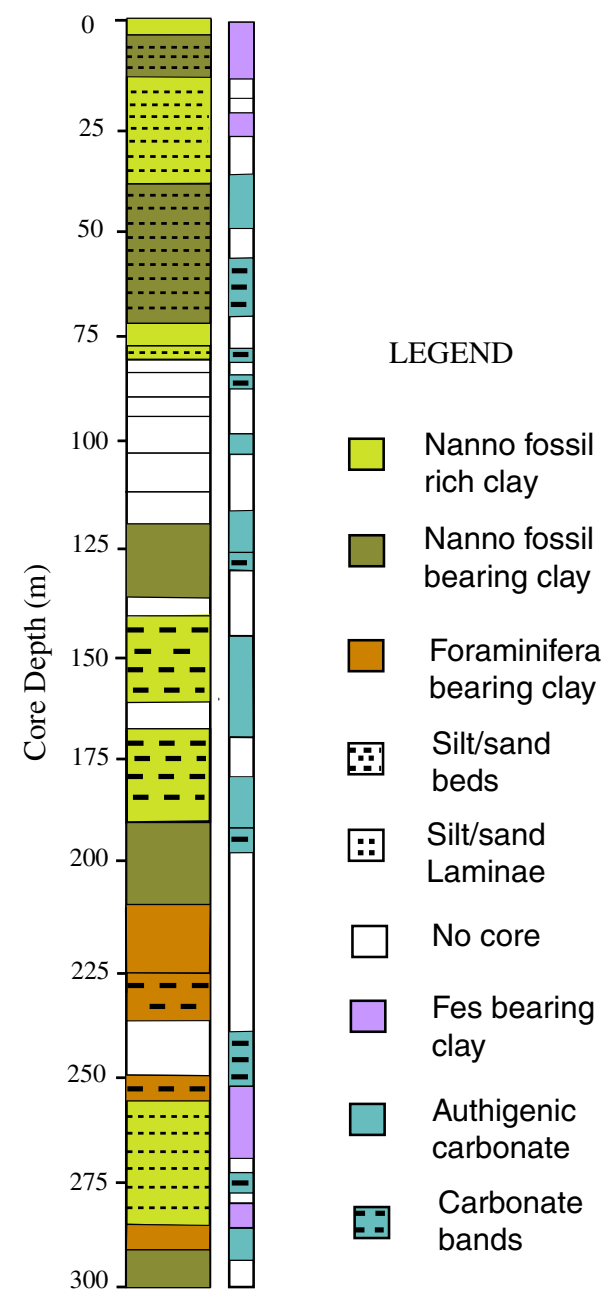

Figure 5. Lithology derived from the drill well data from the location NGHP-01-03B in KG offshore basin.

strata above these folded structures are also characterised by velocity pull-up signatures (anticline shape). The effect of upwelling of Miocene bed can even be seen continued into the upper midPleistocene sequence (figure $4 \mathrm{~b}$ ). The subsurface layers of the upper mid-slope region is also under the influence of excessive formation pressure as evidenced by the presence of domal shaped structures within these strata. The elevated seabed topography (figure 3a) is the resultant of excessive pressures emanating from the deep. Therefore, some of the observed features on the HRS sections are the resultant of the combined effect of reactivation of the tectonics/diapirism aided by deformation. The drilling activity under NGHP (Collett et al. 2008) in the KG offshore basin shows the presence of thick accumulation of gas hydrates deposits in the fractures. Therefore the inferred fractures/faults are significant in assessing the gas hydrates potential of this area. The adjacent subsurface strata in the lower slope region depict the presence of columnar zone $\sim 700 \mathrm{~m}$ wide, which seems to be saturated with the gas (figure 3c). The columnar type gas

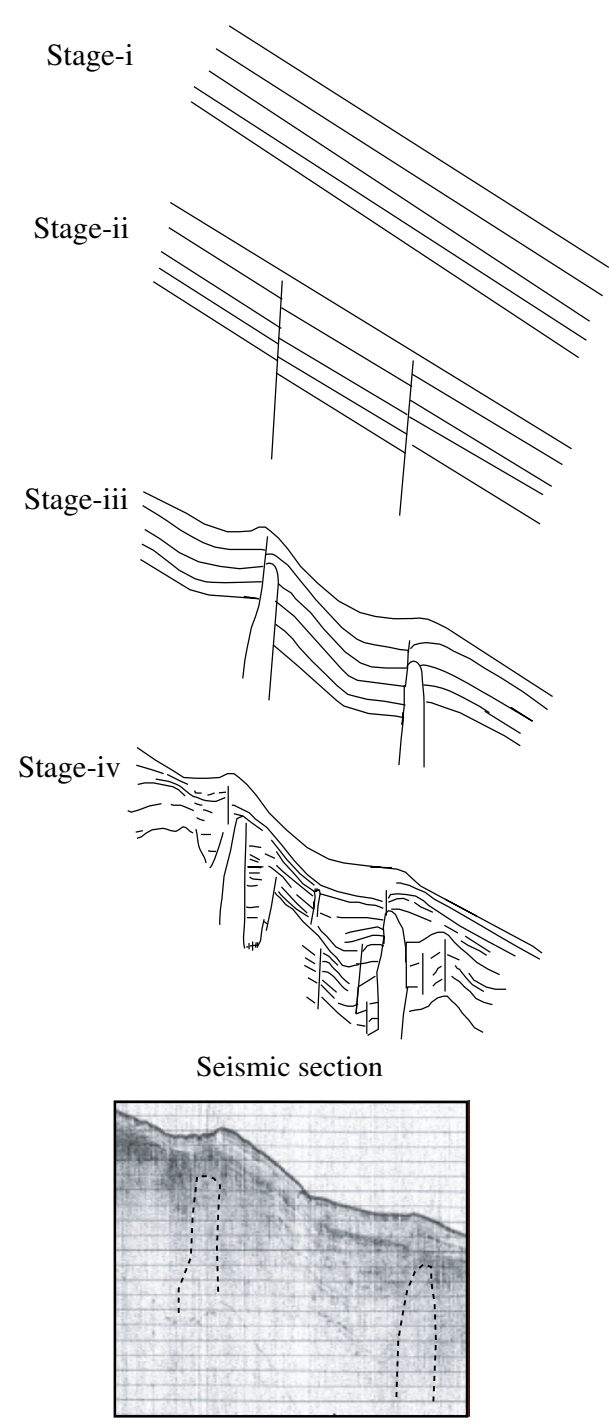

Figure 6. Schematic models explaining the various stages of subsidence of the sedimentary column and shoulder formation on the seafloor. Stage-i represents normal slope sediments and least affected by any tectonic activity during this stage. Stage-ii indicates the neotectonic activity and its influence on the sedimentary strata, which led to faulting. During the stage-iii, these faults remained as pathways/conduits for the continuous upward migration of pressurised gas/fluids, and transformed to columnar type gas saturated zones/vents from fault planes. The enormous gas/fluid venting from the deeper horizons further pushed the entire overlying sedimentary strata, and the rapid pushing/gas-upthrust is responsible for the formation of well developed shoulders on the seabed as observed on the seismic section, and also for the subsidence of the strata in between these shoulders.

saturated zones are found to occur in the deep offshore also. For example, a $\sim 350 \mathrm{~m}$ wide zone exists in the water depths of $\sim 940$ and $\sim 1400 \mathrm{~m}$, respectively. It is interesting to note that these columnar zones extend upwards from the Plio-Pleistocene boundary. The HRS data in conjuncture with the MCS data suggest that the majority of the gasupthrust zones/columnar gas zones are widespread in the upper mid and lower slope regions 
(figure 8), and these features appear to have emanated from the deeper horizons, i.e., late Miocene-Pliocene, and are the manifestation of shale tectonism/mud diapirism. Instances of deformation and neotectonic activity are reported in the eastern continental margin of India (Rao and Mani 1993; Chatterjee et al. 2010). For example, the seismic sections (Krishna et al. 1998) in the distal Bengal Fan depict intense buckling of the basement and the overlying sediments, and effect of buckling can be seen upto late Pleistocene.

\subsection{Deformation/neotectonism}

From the detailed analyses of seismic reflection data it was proposed that the deformation is even periodic (Krishna et al. 1998). The marine geophysical studies (Murthy et al. 2010) led to infer moderate seismicity associated with the landocean tectonic elements along the eastern offshore. Further, the coastal/offshore regions of Visakhapatnam, Ongole and Pondicherry covering the present study area have been identified as zones of weakness where neotectonic activity has been established from the recurrence of earthquakes. Study of the earthquake data over the coastal and offshore areas of Visakhapatnam to Pondicherry reveals prevalence of moderate seismicity (with magnitude of tremors of the order of 3-5.5). The tectonic setting of the east coast of India with predominant $\mathrm{W}-\mathrm{E}$, NW-SE lineaments/fracture system resulted in a basinal to non-basinal mosaic (Murthy et al. 2010) thereby suggesting its vulnerability to neotectonic activity. Further, the high quality marine seismic reflection data (Bastia et al. 2010) shows the deformed sediment overburden over the Early Cretaceous basement, and the impact of deformation is seen even upto the Recent age sediments thereby endorsing the presence of neotectonic activity along the eastern continental margin of India.

The seismic sections (figure 3c) depict a terrace/ flat surface like feature between 1250 and $1500 \mathrm{~ms}$ water depths, and these terrace/flat surfaces are found to occur $\sim 300 \mathrm{~ms}(\sim 240 \mathrm{~m})$ below the seabed. We interpreted this feature as a wide paleo channel which was affected by erosion in the past and the channel flanks remained flat. The tentative age assigned to this reflector is $\sim 1.4 \mathrm{Ma}$ (mid-Pleistocene, average sedimentation rate $0.17 \mathrm{~m} / \mathrm{kyr}$ ). This midPleistocene reflector is seen continuing further offshore and manifested itself into a domal shaped structure (figure $3 \mathrm{c}$ ). The inferred Plio-Pleistocene reflector (acoustic basement) around $562 \mathrm{~ms}$ below the seabed in the mid-slope was found to become shallow towards upper-middle and lower slope regions (figure 3a). Shallowing is due to the intense

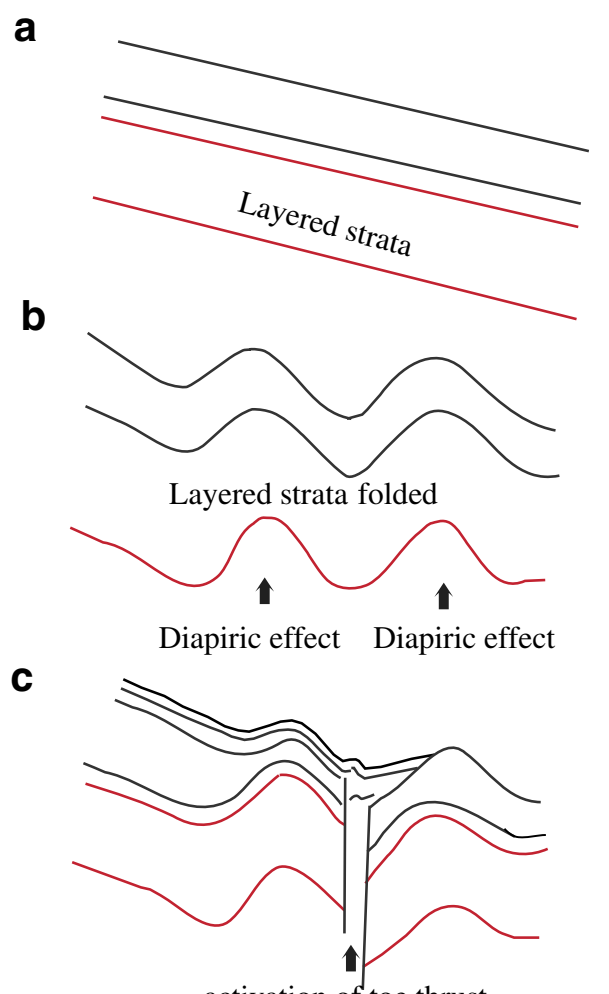

activation of toe thrust

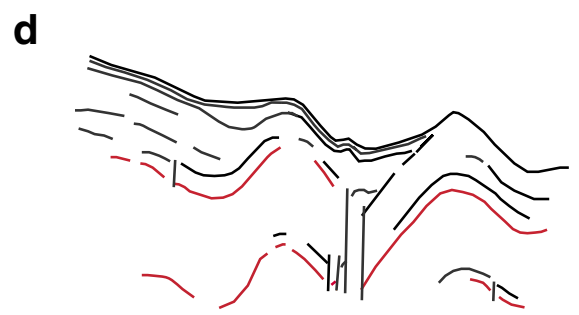

Seismic section

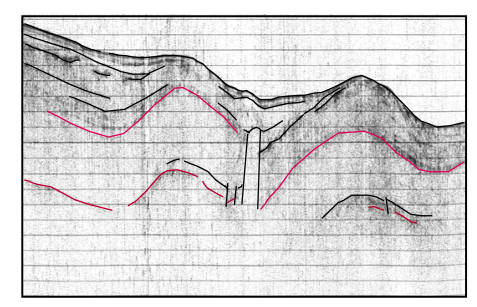

Figure 7. The schematic diagram showing the formation of mounds on the seafloor with columnar type gas/fluid escaping feature. (a) Represents initial configuration of the sediment overburden with parallel reflections. (b) The folded nature of the sediment overburden indicates the influence of compressional forces or underneath diapiric upthrust. Since the horizontal compressional forces are not known in the study area, the folding is attributed to diapiric movement only. (c) Reactivation of the toe thrust fault ruptured the trough between the domal shaped structures and resulted in severe faulting in between the folds. (d) During the subsequent period, through the fault zone, the fluids/gas started rising with enormous pressure upwards and in this process, the complete strata between the fault zone got pushed upward, and the homogenous material spread on the pre-existing trough like formation caused by the faulting/gas-upthrust. 
diapiric activity (vertical compression) associated with gas upthurst, thus giving rise to folded appearance, and sagging of the strata in the middle. The folded structures are seen separated by a huge columnar type wide gas venting feature and the effect of this feature is seen in the upper strata as mini-folded structure. The HRS sections are also characterised with long wavelength folded seafloor topography, a resultant of deep seated diapirism in the lower slope region. The reported high formation pressure and shale tectonism/mud diapirism in the KG offshore (Rao and Mani 1993; Satyanarayana et al. 1996; Sahu 2005; Bastia et al. 2006) corroborate with the wavelength folded features in the lower slope region.

The HRS section (figure 3c) show the presence of a graben-like feature caused by subsidence in the upper slope region and long wavelength folded structures towards the lower slope region. The structures appear to have evolved due to the destabilisation of the slope as well as the gas upthrust/shale tectonism in conjuncture with neotectonic activity. We propose the following mechanism to explain the subsidence and formation of long wavelength undulations on the seabed.

\subsection{Mechanism for subsidence and folded structures}

Mechanism for the subsidence has been explained through the following four stages (figure 6). Stage (i) represents the initial layered strata that did not experience either tectonic activity or destabilisation of the sedimentary column due to slope failure. The stage (ii) indicates impact of the neotectonism that resulted in severe faulting (figures $3 \mathrm{c}$ and 6). During the stage (iii), these

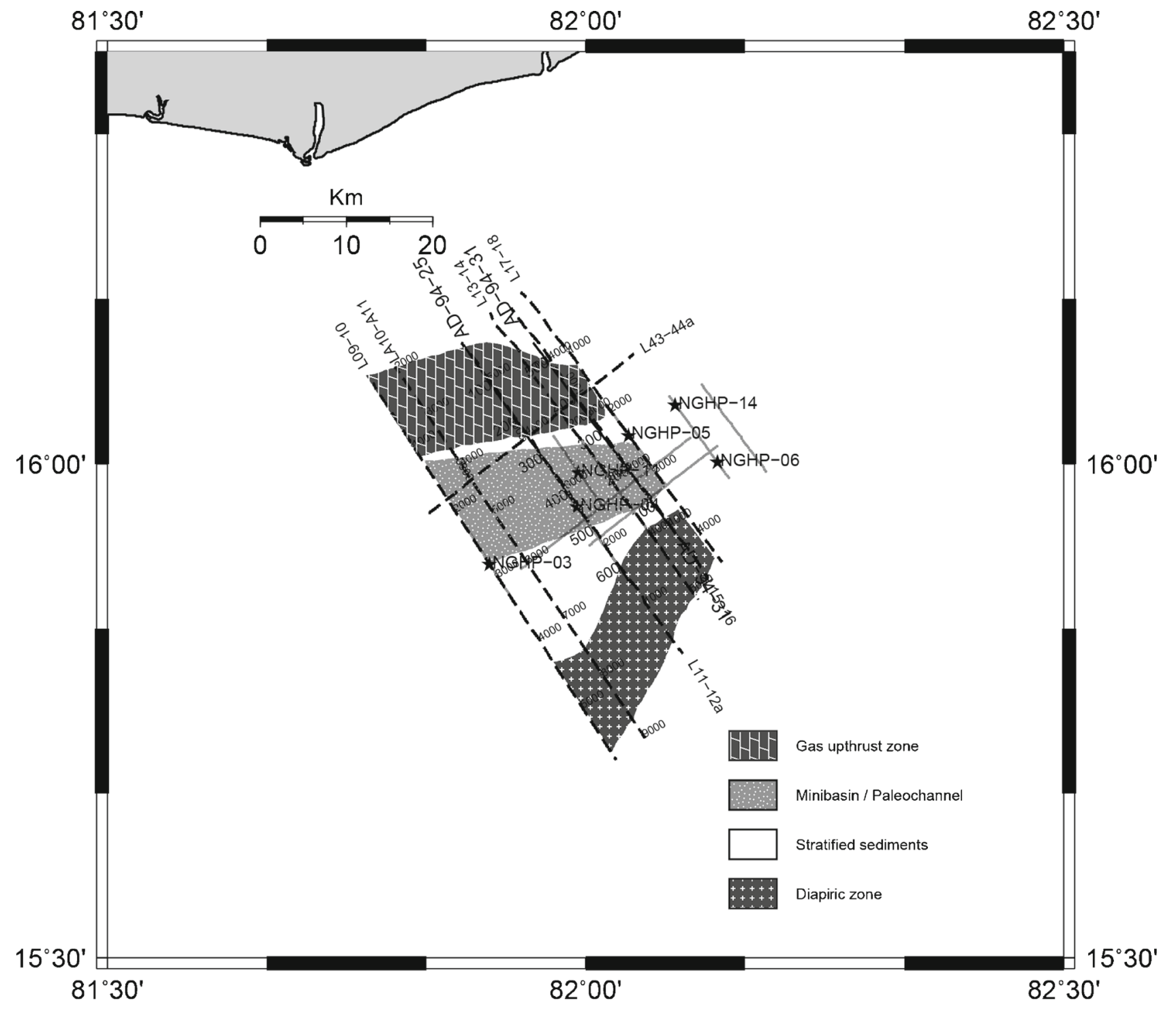

Figure 8. Map showing the extent of various geological features as deduced from seismic interpretation. 
fault planes appear to serve as pathways/conduits for the upward migration of pressurised gas/fluids from the deep, and facilitated in transformation of the fault planes into columnar type gas saturated zones/vents (figures $3 \mathrm{a}-\mathrm{c}$ and 6 ). The continuous upward flow of enormous gas/fluid from the deeper horizons resulted in further upwarping of the entire overlying sedimentary strata as shown in stage (iv). Further, the rapid pushing/gas-upthrust (Chatterjee et al. 2010) is responsible for the development of well defined shoulders on the seafloor as observed (figure 3a) and resulted in the collapse/ subsidence of the strata in between the shoulders (figures 3c and 6). Similarly, the following mechanism has been proposed to explain the observed folded structures. Initially, the seabed and the sedimentary column beneath was stratified (figure 7a) and then affected by the deep seated diapirism, which pushed upward the entire sequence giving rise to domal shape appearance (figure $7 \mathrm{~b}$ ). With the activation of the toe thrust fault, both the domal shaped structures were faulted (figure $7 \mathrm{c}$ ). Subsequently, the upward migration of fluids/gas through the fault zone, started rising with enormous pressure upwards. During this process, the complete strata within the fault zone got pushed upward, and the homogenous material spread on the pre-existing trough like feature caused by the faulting/gas-upthrust (figure 7d).

The observed sag/depression in the upper mid-slope region is interpreted as mini basin (figure 3d), and these mini-basins are evolved from the gas upthrusts/neotectonic activity. This minibasin is filled with Late Pleistocene $(\sim 0.28 \mathrm{Myr})$ to Recent sediments. The HRS sections distinctly show the presence of another basin/depression like feature in the mid-shelf region (figure $3 \mathrm{c}$ ). Integrated interpretation of the data (bathymetry, HRS and MCS) under the constraints of the results obtained from drilling elucidate that the gas-upthrust zone is confined to a larger extent to the upper mid-slope region, while the effect of diapirism is felt along the lower slope region. The lateral and vertical extension of this mini-basin (sagging structure) has been mapped from the seismic reflection data. The lateral extent of this basin is about $45 \mathrm{~km}$ in a SW-NE direction (figure 8), and appears to be a depocentre with maximum thick sediments $(\sim 450 \mathrm{~m})$ towards $\mathrm{SW}$ and $\sim 100 \mathrm{~m}$ towards NE of the study area. Interestingly the mid-slope region host gas hydrates accumulations in fractures.

\section{Conclusions}

The depth to the seabed in the KG offshore basin varies between $<375$ and $1600 \mathrm{~m}$, with an average gradient of 1:37. The seabed topography has been divided into three zones, i.e., upper slope (375-450 m), mid-slope (450-1120 m) and lower slope $(1120-1600 \mathrm{~m})$. Interpretation of the HRS reflection data along the dip line shows a maximum penetration of $\sim 562 \mathrm{~ms}(450 \mathrm{~m})$ below the seabed and well defined lithological boundaries within the Quaternary-Recent sediments with a vertical resolution of $\sim 2 \mathrm{~m}$. The sediments are associated with gas escape features (blanking zones, columnar type gas vents, fault controlled mud diapirs, large dimension gas saturated zones, surface mounds, etc). Integrated study indicates that this shale diapirism is evident from the mid-late Miocene onwards and continues even upto Recent time. The sediments below the upper mid-slope region are severely faulted, and the strata attains domal shape (anticline like structure) with considerable wavelengths. Drill well data facilitated in identification of extension of nannofossils bearing rich clay up to $300 \mathrm{~m}$ with $\sim 10-20 \mathrm{~m}$ incursions of foraminifera bearing clay and nannofossil bearing rich clay beds. The top $\sim 10-30 \mathrm{~m}$ layer comprised mainly fine clay associated with an acoustic transparent character, and the sediments rest on the LGM surface. The observed long wavelength undulations in the lower slope region are the manifestation of deep seated shale tectonism/neotectonic activity. The shallow geological formations are affected by gas upthrusts in the upper slope region, and these gas features emanate from deeper levels. The lower slope region is extensively influenced by shale tectonism in combination with the neotectonism. The mid-slope with its thick sediments appears to be potential.

\section{Acknowledgements}

The authors sincerely thank Director, National Institute of Oceanography, Goa for granting necessary permission to publish this manuscript. G Anitha (SRF) would like to thank Smt. Vimalabai (Jiji) Neelkanth Jatar Charitable Trust (VNJCT) for the financial support through institution of fellowships for the award of Ph.D. in gas hydrates studies. M V Ramana like to thank CSIR-Emeritus scientist scheme for financial assistance. This is NIO Contribution No. 5455.

\section{References}

Bastia R 2004 Deposition model and reservoir architecture of tertiary deep water sedimentation, Krishna-Godavari offshore basin, India; J. Geol. Soc. India 64 11-20.

Bastia R and Nayak P 2006 Tectonostratigraphy and depositional patterns in Krishna offshore basin, Bay of Bengal; The Leading Edge 25(7) 839-845. 
Bastia R, Singh P and Nayak P 2006 Linking shelf delta to deep water: Krishna-Godavari Basin; Geol. Soc. India $167618-628$.

Bastia R, Radhakrishna M, Srinivas T, Satyabrata Nayak, Nathanial D M and Biswal T K 2010 Structural and tectonic interpretation of geophysical data along the eastern continental margin of India with a special reference to deep water petroliferous basins; J. Asian Earth Sci. 39 608-619.

Chatterjee R, Mukhopadhyay M and Paul S 2010 Overpressure zone under the Krishna-Godavari offshore basin: Geophysical implications for natural hazard in deeper-water drilling; Nat. Hazards, doi: 10.1007/s11069-010-9659-6.

Collett T S, Riedel M, Cochran J R, Boswell R, Presley J, Sibal V, Kumar P, Sathe A, Sethi A and Lall M 2008 The National Gas Hydrates Program Expedition 01 Initial reports, Directorate General of Hydrocarbons, Ministry of Petroleum and Natural Gas, New Delhi.

Curray J R, Emmel F J, Moore D G and Raitt R W 1982 Structure, tectonics and geological history of the northeastern Indian Ocean; In: The Ocean basins and margins (eds) Nairn A E and Stehli F G (New York: Plenum Press) 6 399-450.

Dewangan P, Ramprasad T, Ramana M V, Mazumdar A, Desa M and Badesab F K 2010 Seabed morphology and gas venting features in the continental slope region of Krishna-Godavari basin, Bay of Bengal: Implications in gas-hydrate exploration; Mar. Petrol. Geol. 27(7) 1628-1641.

Dewangan P, Sriram G, Ramprasad T, Ramana M V and Jaiswal P 2011 Fault system and thermal regime in the vicinity of site NGHP-01-10, Krishna-Godavari basin, Bay of Bengal; Mar. Petrol. Geol. 28 1899-1914.

Gupta S K 2006 Basin architecture and petroleum system of Krishna Godavari basin, east coast of India; The Leading Edge 25(7) 830-837.

Kvenvolden K A 1993 Gas hydrates as a potential energy resource - a review of their methane content; In: The Future of Energy Gases (ed.) Howell D G, US Geol. Surv. Prof. Paper 1570 555-561.

Krishna K S, Ramana M V, Gopala Rao D, Murthy K S R, Malleswara Rao M M, Subrahmanyam V and Sarma K V L N S 1998 Periodic deformation of oceanic crust in the central Indian Ocean; J. Geophys. Res. 103 17,85917,875 .

Mazumdar A, Dewangan P, Joao H M, Peketi A, Khosla V R, Kocherla M, Badesab F K, Joshi R K, Roxanne P, Ramamurty P B, Karisiddaiah S M, Patil D J, Dayal A M, Ramprasad T, Hawkesworthn C J and Avanzinelli R 2009 Evidence of paleo-cold seep activity from the Bay of Bengal, offshore India; Geochem. Geophys. Geosys. 10(6) 15, doi: 10.1029/2008GC002337.

Mazumdar A, Peketi A, Dewangan P, Kocherla M, Joshi R K and Ramprasad T 2012 Geochemical and geological constraints on the composition of marine sediment pore fluid: Possible link to gas hydrate deposits; Mar. Petrol. Geol. 38 35-52.

Murthy K S R, Subrahmanyam V, Subrahmanyam A S, Murty G P S and Sarma K V L N S 2010 Land-ocean tectonics (LOTs) and the associated seismic hazard over the Eastern Continental Margin of India (ECMI); Nat. Hazards 55 167-175, doi: 10.1007/s11069-010-9523-8.
NIO 1997 Gas hydrates resource map of India; No. NIO/SP25/97, National Institute of Oceanography, Dona Paula, Goa.

NIO 2001 Reprocessing of multichannel seismic data of ONGC; No. NIO/CON/3-2001, National Institute of Oceanography, Dona Paula, Goa.

NIO 2005 Geoscientific investigations of shallow sediments in KG offshore, East Coast; NIO/TR-13/2003, National Institute of Oceanography, Dona Paula, Goa.

Pateria M L, Rangaraju M K and Raiverman V 1992 A note on the structure and stratigraphy of Bay of Bengal sediments; In: Recent Geoscientific Studies in the Bay of Bengal and the Andaman Sea; Geol. Surv. India Spec. Publ. 29 21-23.

Raju D S N, Ravindran C N, Mishra P K, Chidambaram L and Saxena R K 1994 Stratigraphy and Paleoenvironments of the Godavari clay in the Krishna-Godavari basin, India; Indian J. Petrol. Geol. 3(2) 33-43.

Ramana M V, Nair R R, Sarma K V L N S, Ramprasad T, Krishna K S, Subrahmanyam V, Maria D'Cruz, Subrahmanyam C, Paul J, Subrahmanyam A S and Chandra Sekhar D V 1994 Mesozoic anomalies in the Bay of Bengal; Earth Planet. Sci. Lett. 121 469-475.

Ramana M V, Ramprasad T, Desa M, Sathe A V and Sethi A K 2006 Gas hydrates-related proxies inferred from multidisciplinary investigations in the Indian offshore areas; Curr. Sci. 91(2) 183-189.

Ramana M V, Ramprasad T, Paropkari A L, Borole D V, Ramalingeswara Rao B, Karisiddaiah S M, Desa M, Kocherla M, Joao H M, Loka-bharathi P, Gonsalves Maria-Judith, Pattan J N, Khadge N H, Prakash Babu C, Sathe A V, Kumar P and Sethi A K 2009 Multidisciplinary investigations exploring indicators of gas hydrates occurrence in the Krishna-Godavari basin offshore, east coast of India; Geo-Mar. Lett. 29(1) 25-38.

Ramprasad T, Dewangan P, Ramana M V, Mazumdar A, Karisiddaiah S M, Ramya E R and Sriram G 2011 Evidence of slumping/sliding in Krishna Godavari offshore basin due to gas/fluid movements; Mar. Petrol. Geol. 28 1806-1816.

Rao G N 2001 Sedimentation, stratigraphy, and petroleum potential of Krishna-Godavari basin, east coast of India; Am. Assoc. Petrol. Geol. Bull. 85(9) 1623-1643.

Rao G N and Mani K S 1993 A study on generation of abnormal pressures in Krishna-Godavari Basin, India; Indian J. Petrol. Geol. 2(1) 20-30.

Sahu J N 2005 Deep water Krishna-Godavari basin and its potential; Petromin (Asia's Exploration and Production Business magazine) 31 26-34.

Satyanarayana K, Rao G N, Bhavana P R, Sinha H R and Banerjee A N 1996 Miocene sedimentation in subsurface of Godavari Delta; Bull. ONGC 33(1) 77-92.

Shanmugam G 2009 Slides, slumps, debris flows, and turbidity currents; In: Encyclopaedia of Ocean Sciences (eds) Steele J H, Turekian K K and Thorpe S A, 2nd edn, Elsevier, pp. 447-467.

Shanmugam G, Shrivastava S K and Das B 2009 Sandy debrites and tidalites of pliocene reservoir sands in upperslope canyon environments, offshore Krishna-Godavari basin (India): Implications; J. Sedim. Res. 79(9) 736756.

Sloan E D 1990 Clathrate Hydrates of Natural Gases, Marcel Dekker, Inc., New York. 